\title{
A composiçãa espacial das rádios livres: trajetórias, lugares e escalas
}

\section{The space composition of free radio: trajectories, places and scales}

\section{Resumo:}

Este artigo busca compreender o modo como o espaço geográfico constitui as rádios livres, apresentando resultados de uma pesquisa concluída. Sua metodologia compreendeu um levantamento bibliográfico por meio do qual se interpretou a história do movimento social de rádios livres, suas relações com o Estado e outros movimentos sociais de democratização da comunicação. Em seguida, realizaram-se estudos de caso com integrantes de três rádios livres localizadas no estado de São Paulo, com entrevistas e trabalhos de campo. Pode-se entender que a espacialidade das rádios livres, produzida pelas múltiplas trajetórias dos integrantes, proporciona a formação de lugares do acontecer solidário, em que os sujeitos dialogam sobre uma infinidade de temas marginalizados e realizam atividades de cunho formativo cotidianamente, oportunizando uma produção da escala geográfica diferenciada, bem como uma distribuição da técnica de maneira crítica.

\section{Abstract:}

The following article is the result of a completed research that aims to understand how the geographical space recently comprises the constitution of free radio. Our methodology comprises a literature review, interpreting the history of the social movement of free radio stations and their relations with the state and other social movements of democratization of communication. Then, there were case studies with members of three free radio stations that are located in the state of São Paulo, with interviews and field work using a participant observation and some researches actions. We can understand that the spatiality of free radios produced by the multiple trajectories of the members provided training places of solidarity happenings, talking about a multitude of subjects marginalized and conducting formative imprint daily activities, providing a differentiated production of geographical scale and a distribution of technical critically.
André de Souza Fedel * Almir Nabozny **

* Graduado em Geografia pela Universidade Estadual de Ponta Grossa (UEPG). Mestrando em Geografia na Universidade Federal do Paraná (UFPR).

** Doutor em Geografia pela Universidade Federal do Rio Grande do Sul (UFRGS). Professor adjunto no Departmento de Geociências da UEPG.

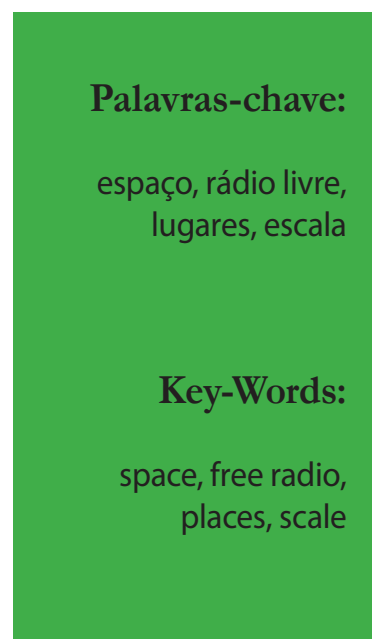


INTRODUÇÃO: COMUNICAÇÃO E RADIODIFUSÃO

$\Delta$ prática da comunicação está presente em toda a história humana e é elemento fundador da construção da territorialidade, das fronteiras políticas e dos territórios nacionais, por exemplo. A partir do momento em que a comunicação oral e cotidiana descobre sistemas técnicos como instrumentos para romper o espaço, reduzir o tempo e transmitir mensagens, muitas fronteiras, territorialidades e territórios nacionais sofrem transformações em seu interior. Neste processo ainda em curso, a maioria dos agentes possui objetivos claros que favorecem somente àqueles que dominam as comunicações de massa. Entretanto, de maneira invisibilizada e marginalizada na história da radiodifusão brasileira, muitas organizações, movimentos sociais e coletivos apropriaram-se da técnica para propor outra comunicação.

Neste artigo, destaca-se essa outra comunicação para se construir uma compreensão geográfica do fenômeno da radiodifusão livre. Para isso, inicialmente elaborou-se com o levantamento bibliográfico um breve panorama histórico da produção da voz oficial. Depois, ao ponto de no período atual observar a organização, os movimentos, as iniciativas e as práticas espaciais das rádios livres, realizou-se uma reflexão dessa composição a partir das trajetórias dos sujeitos e coletivos envolvidos, suas ações espacialmente referenciadas e seus conteúdos produzidos constituindo a voz não oficial. Por fim, lançam-se questões que podem concluir o processo da pesquisa, porém suscitam a atenção, a nosso ver, de outros trabalhos de pesquisas e ações comprometidas.

\section{A PRODUÇÃO DA VOZ OFICIAL NOS MEIOS DE COMUNIÇAÇÃO}

Tomamos como marco na produção da voz oficial o contexto das grandes guerras e o acelerado desenvolvimento industrial gerado por demandas dos Estados Nacionais Modernos. Essas exigências referem-se ao domínio de territórios e podem ser compreendidas como: a corrida pelo controle da produção de tecnologia, controle social de populações e, também, no domínio de recursos minerais.
Da mesma forma, isso ocorre no contexto das comunicações e, especificamente, do rádio, então recém inventado:

A disputa técnica, especialmente durante a Primeira Guerra Mundial, permite que o rádio se desenvolva de forma acelerada e, em menos de vinte e cinco anos da primeira transmissão, ele já começa a fazer parte do cotidiano internacional. Rapidamente, os Estados Unidos entram na concorrência, que obedece a linha da melhor performance técnica, e levam vantagem. Grandes conglomerados econômicos, como a Westinghouse, começam a exportar equipamentos transmissores para vários países, entre eles o Brasil (NUNES, 1995, p. 10).

À medida que a técnica de radiodifusão era aprimorada e otimizadas às suas funcionalidades, concomitantemente, empreendiam-se transformações na ordem social e organizacional:

Houve mais mudanças que continuidade na educação e no entretenimento durante os séculos XIX e XX. A maioria delas é explicável em termos econômicos e sociais, desde que se incorpore na análise a tecnologia, tratada como uma atividade social, envolvendo pessoas, produtos e patentes (BRIGGS e BURKE, 2006, p. 189).

Briggs e Burke (2006) discorrem que esse período de alta industrialização:

(...) demandava uma circulação de informação mais substancial e confiável, tanto por motivos financeiros quanto para o controle dos processos industriais (...). Assim a instrução de massa era agora julgada essencial, assim como a educação continuada e o aprendizado da computação se tornaram imprescindíveis nas últimas décadas do século XX (BRIGGS e BURKE, 2006, p. 189).

Essa instrução de massa, oral e cotidiana, aprofundava-se, consequentemente, na relação da construção do espaço político e econômico da sociedade por meio, por exemplo, da adoção de modelos técnicos e da introdução de publicidade nos meios de comunicação:

O reconhecimento da força de persuasão através do rádio e de suas possibilidades de uso político determina a concentração do monopólio da comunicação social, no mundo inteiro, em poder do Estado, explorando ele mesmo os serviços de radiodifusão, como no modelo europeu, ou repassando-os através de concessão para a iniciativa privada, conforme o padrão americano. O Brasil adotou este último modelo, reforçando, porém, a exploração comercial da radiodifusão (NUNES, 1995, p. 10).

(...)

A década de 30 é marcada por uma nova fase, quando é introduzido o receptor a válvula, barateando a produção 
e aumentando o consumo de aparelhos. O lado comercial é incentivado e o governo permite que $10 \%$ da programação se destine a inserções publicitárias, bem como institui a obrigatoriedade da transmissão simultânea em todas as rádios de um programa nacional, produzido pelo Serviço de Publicidade da Imprensa. Posteriormente os índices de publicidade são alterados para $20 \%$ e $25 \%$, este último perdurando até os dias atuais (NUNES, 1995, p. 27).

A radiodifusão, centrada no controle do Estado, traduz-se em correia de transmissão política e propagação de formas simbólicas de dominação (ideologia). Em grande parte da historiografia dos meios de comunicação, concebe-se a coexistência entre o período de consolidação do Estado-NaçãoModerno (Ocidental) e de organizações supranacionais como sendo a "gestação" da voz oficial.

Na América Latina, em especial no Brasil, no contexto da Segunda Guerra Mundial, a Organizações das Nações Unidas (ONU), através da Organização das Nações Unidas para a Educação, a Ciência e a Cultura (UNESCO), foi um órgão em escala internacional responsável pela propagação e incentivo de políticas de expansão das redes de comunicação e controle de informação (ANDRIOTTI, 2004). Essas ações estão inseridas em contexto de desenvolvimento das forças produtivas, como, por exemplo, a modernização da agricultura através da tecnologização e da quimificação do campo (Revolução Verde, etc.).

Nesse ínterim, em escala nacional (Brasil), é instaurado o regime militar, operacionalizando a implantação de um sistema de comunicações. A Empresa Brasileira de Telecomunicações (EMBRATEL), o Ministério das Comunicações (MiniCom) e a extinta Telebrás (Telecomunicações Brasileiras S.A) são criados entre o final da década de 1960 e início da década de 1970 e, inteiramente repassados aos empresários da comunicação (GUARESCHI e BIZ, 2005), que acabavam de organizar-se na Associação Brasileira de Rádio e Televisão (ABERT) (GONÇALVES, 2010). Deste modo, as redes de comunicação compuseram o papel fundamental de (re)forçar um movimento de integração territorial nacional (NUNES, 1995), evidenciando, assim, o aspecto de concentração da produção de conteúdo midiático.

A revolução técnica-científica-informacional, abordada por Milton Santos (2008) apontou essa característica da desigualdade da distribuição das técnicas e, por conseguinte, a mundialização da cul- tura, demonstrando que além do consumo material como meio de integração, há o domínio específico de uma cultura (ORTIZ, 2000). Downing (2002) afirma que a mídia convencional, por meio das notícias, da ficção, dos esportes, da comédia, de programas infantis e musicais, entre outros "atrativos", vai inserir-se no campo social de tal forma que outras instituições, como a família e a igreja, já não conseguem dialogar com as pessoas sobre uma infinidade de temas. Essa substituição, além de criar uma fratura na comunicação intersubjetiva, virtualiza muitos problemas concretos, atinentes às condições materiais de existência.

\section{LIBERDADE DE EXPRESSÃO, AS VOZES NÃO OFICIAIS E A APROPRIAÇÃO DOS MEIOS DE COMUNICAÇÃO}

Neste contexto - de uma modernização técnica centralizadora, uma gestão e uma mediação cultural empreendida por empresários familiares e pelo Estado brasileiro - se inserem, paralelamente, às iniciativas populares de apropriação "não autorizadas" do rádio por indivíduos, grupos e movimentos sociais (MACHADO et al, 1987; NUNES, 1995; ANDRIOTTI, 2004; SERPA, 2011; GONÇALVES, 2010; GONÇALVES, 2012; COSTA, 2013). Por 'gostar de fazer rádio', os primeiros indivíduos e associações de radioamadores utilizavam o rádio para uma comunicação sem muitos objetivos políticos. Com o regime militar na frente das decisões políticas e econômicas do país por mais de uma década, em 1980 surgem várias iniciativas que construiriam o embrião de um movimento de rádios livres e de democratização direta da comunicação. Em Belo Horizonte-MG, em Sorocaba-SP e em Vitória-ES há os primeiros registros. Logo após, principalmente em Sorocaba, forma-se uma espécie de organização para auxiliar as rádios nascentes, principalmente para ocupar frequências vazias. Marisa Nunes delineia as características desse movimento

Os contornos dessa intervenção coletiva foram de desobediência civil declarada, e o apartidarismo em que se manifestaram às aproximam de uma forma pura de luta pela democracia (NUNES, 1995, p. 51).

As vozes não oficiais levantadas, foi um movimento em grande parte realizado pela juventude da cidade, além de ser ameaçado e reprimido pelo 
extinto DENTEL (Departamento Nacional de Telecomunicações). Esse ocorrido reverberou em São Paulo e foi fagulha na criação da Rádio Xilik. Ao olhar de Cristiane Andriotti

A Rádio Xilik inaugura uma proposta de rádio livre engajada no movimento pela democratização dos meios de comunicação. As diferenças entre esta experiência e as experiências de Sorocaba, é que a Xilik é mais politizada. Ela não apoia apenas a possibilidade de qualquer um poder ter a sua rádio no "ar", mas defende que este veículo de comunicação deve ser apropriado principalmente pelos movimentos sociais organizados (ANDRIOTTI, 2004, p. 33).

Tão logo a formação de entidades e organizações para a cooperação das Rádios Livres surgiu, em todo país foram sendo efetuados os registros. Segundo Mauro Costa

Na primeira tentativa de juntar emissoras de vários estados, em 1986, no Rio de Janeiro formaram-se duas entidades: a ABOLA, Associação Brasileira das Ondas Livres do Ar e a Cora-Libra, Cooperativa de Rádios Livres do Brasil (COSTA, 2013, p. 118).

Em nosso levantamento bibliográfico, há claros indícios de que a efervescência das rádios livres foram muito impulsionadas na década de 80 e início de 90 pela grande censura e repressão que ocorriam em qualquer espaço em que se pretendia discutir e praticar outra política. Também se destaca que esse movimento alimentou tanto setores progressistas da igreja católica, que já se articulavam nas CEB's (Comunidades Eclesiais de Base) inspirados na Teologia da Libertação, quanto movimentos sociais que tinham objetivos claros nas reformas estruturais do Estado brasileiro. Alguns integrantes de Rádios Livres organizam um clássico sobre o tema. O livro "Rádios Livres, a reforma agrária no ar" populariza no país a questão da democratização da comunicação. Nessa altura, havia rádios em hospitais psiquiátricos, em aldeias indígenas, favelas, núcleos de partidos ainda na ilegalidade e entre outros lugares, revelando a voz não oficial que era frequente na comunicação cotidiana destes segmentos da sociedade.

Neste contexto, tensiona-se a noção de soberania nacional do Estado (SMITH, 1996) pela produção política da escala geográfica (SMITH, 2000), sustentadas em táticas (CERTEAU, 1998) dos diversos grupos (praticantes das rádios livres) enlaçados aos lugares, mas transversalmente articulados.
Assim, o modo como é pensado o espaço geográfico reforça a ideia de tática concebida por Certeau (1998), em específico no cotidiano, nas concepções de mundo, no modo de fazer política, entre outros aspectos, pois "O espaço é uma multiplicidade discreta, cujos elementos, estão, eles próprios, impregnados de temporalidade" (MASSEY, 2008. p.89). Com essa ideia de repensar o espaço, ele próprio se constitui como interação. Nos estudos de casos em tela, pontuam-se as interações das multiplicidades de trajetórias e vozes dos agentes constituidores das rádios.

As rádios como espacialidades da multiplicidade possibilitam um potencial criativo de ideias, de histórias, de mobilidade de pessoas e de ações promovidas pelos programadores e pelas programadoras. Os integrantes das rádios, através de suas experiências cotidianas, compartilham ideias em momentos fixos, como as reuniões, em que discutem propostas de atividades a serem realizadas, assim como os programas, estabelecendo, assim, novas demandas e discussões (fluxos). Desta maneira, não há como conceber o espaço como um recorte estático temporalizado em um sistema fechado, pois a concepção estática ignora as múltiplas trajetórias (MASSEY, 2008) de encontros e de ações coletivas.

Deste modo, os encontros-espaciais no âmbito do saber-fazer das rádios em que trajetórias de vida se encontram, as interações são, justamente, viabilizadas pelas “(...) diferentes visões de mundo e das diferenciadas ideias de cultura. Essa vida cotidiana é condensada de ações e essas ações partem de um lugar Agrupando as ações, pode-se afirmar um 'enredo do lugar'" (SERPA, 2011. p.23). Assim, em nossos estudos de casos, que se ambientam na experiência urbana, questiona-se quem são os sujeitos que narram (concebem) os enredos dos lugares:

Se considerarmos o espaço público da cidade contemporânea como o espaço da ação política e do embate/conflito entre as diferentes ideias e concepções de cultura, então as rádios livres ou comunitárias e os domínios virtuais alternativos podem ser considerados como entrelugares do acontecer político e cultural que se transformam paulatinamente em objetos urbanos apropriados de modo criativo e político pelas classes populares. Lugares do possível e entrelugares do acontecer solidário que renovam a esfera pública urbana, possibilitando também novas estratégias e táticas de planejamento da cidade e do urbano (SERPA, 2011, p. 31-32). 
Esta propensão das relações de lugares expressadas por Serpa (2011) pode configurar o saltar de escalas preconizadas por Smith (2000). Oferecese uma redefinição da escala da vida cotidiana para os integrantes das rádios, em que a interação produzida na própria escala angaria táticas de resistência política, isto é, de discussão e orquestração dos conflitos sociais, buscando a sua superação, inicialmente por meio da comunicação e do diálogo sobre estes conflitos. Não obstante, esta escala é duplamente interseccionada pela tensão com a soberania do Estado em relação ao direito de comunicar e, ao mesmo tempo, na interação de temáticas do cotidiano transpassadas pela "técnica-territorializada".

\section{METODOLOGIA EM DISCUSSÃO}

Com um levantamento bibliográfico para construção de um corpus de pesquisa (BAUER; AARTS, 2008) e trabalhos de campo utilizando a observação participante (THIOLLENT, 1992) e apoiando-se em fotografias, foram realizadas entrevistas semi-estruturadas e entrevistas episódicas (FLICK, 2008), utilizando-se métodos de análise de interpretação de texto, análise retórica e análise argumentativa (LIAKOPOULOS, 2008).

Para tanto, a temporalidade enfocada compreende desde as memórias (entrevistas) dos agentes em relação aos momentos de elucubração das rádios, até os recentes anos de 2011, 2012 e 2013, quando realizamos observações sistemáticas nos trabalhos de campo nas rádios, em eventos a respeito do espectro livre' e na leitura de debates em coletivos ${ }^{2}$ de rádios livres angariados na rede mundial de computadores.

Foram realizadas seis entrevistas semi-estruturadas de modo a se entender o significado de rádio livre para os integrantes, a motivação na sua participação e o que proporcionava tais atividades desempenhadas nas/pelas rádios livres.

Nessas entrevistas, podemos entender as discussões dos integrantes como a questão da apropriação técnica da radiodifusão, fundamentando-se como elementos essenciais para a autonomia dos coletivos de rádios livres. No entanto, esta situação traz insegurança a todos, pois perante os órgãos do Estado (noção de soberania), esta prática é vista como criminosa. Os integrantes dos movimentos de rádios livres consideram que a legislação é controversa e que, majoritariamente, quem a instrumentaliza, por exemplo, na "apreensão de equipamentos", são os representantes de meios de comunicação convencionais, em sintonia com a Agência Nacional de Telecomunicações (ANATEL) e as ações da Polícia Federal.

Em relação à dinâmica interna das rádios livres, tem-se por um lado uma exaltação da facilidade de ingresso e aceitação de novos integrantes. No entanto, por parte de alguns programadores, com mais anos de experiência, ouviram-se críticas a respeito da atual formação política dos novos integrantes, colocando como fragilidades da organização cotidiana hodierna. Em termos de caracterização das rádios, há também a formação de estúdios livres, o que fornece oportunidades para bandas e grupos musicais independentes que estabelecendo relações de apoio mútuo com a rádio.

Como as rádios elegidas (para os estudos de caso) possuem uma distância física considerável, optamos também pela inserção em listas de discussões na Internet. Assim, mantivemos contato com as ideias de ações e debates que acontecem entre os coletivos destas rádios, expandindo o nosso corpus de investigação.

Por conta das ações percebidas no campo, aparentemente fluídas desempenhadas pelas rádios em espaços específicos, isto é, variabilidade de rotinas e contínuas alternâncias de integrantes nas rádios, utilizou-se na pesquisa de entrevistas episódicas em encontros esporádicos, totalizando quatro entrevistas nesse formato. Dentre os trabalhos, adotou-se a tática investigativa do 'movimento'. Movimentos para alcançar, encontrar, visualizar e refletir sobre o leque de atividades realizadas pelos integrantes de rádios livres. Esses encontros foram importantes para a compreensão da formação, da história e da inserção dos integrantes (nas rádios e outros movimentos), estes momentos agregaram "experiências à pesquisa" na medida que o campo de investigação concomitantemente passa a constituir as técnicas de pesquisas Nestas entrevistas, podemos conceber as estratégias entre sujeitos e/ou entidades para estabelecer uma rádio livre, e as dificuldades de se realizar uma grade de programação com moradores dos próprios bairros onde a rádio está inserida. Ainda há muitos obstáculos entre 'quem só ouve e quem fala', o que motiva os integrantes das rádios a adotarem 
atividades para expor a rádio em espaços públicos, realizando debates sobre o cotidiano do bairro e, consequentemente, desconstruindo o abismo entre emissor e receptor.

Podemos ressaltar a pesquisa participante em alguns dos trabalhos de campo realizados em práticas de oficinas, debates políticos, formações técnicas, festivais artísticos. Houve participação em fóruns (na internet e pessoalmente) de ampliação de temáticas, os quais são realizados com frequência e tem como objetivo a fundamentação de pautas e de táticas de ações. Em um dos trabalhos de campo, no ano de 2013, acompanhamos uma oficina técnica e política de rádio com integrantes da Rádio Muda em um assentamento rural no interior do estado de São Paulo (Figura 1), quando conhecemos uma integrante da Rádio da Juventude e, também, realizamos entrevistas, a fim de entender essa mobilidade e a situação da Rádio da Juventude. Notamos que muitas dessas atividades se enlaçam com pautas de movimentos sociais, como o estudantil, de luta pela terra, direitos humanos, feminismos, causa indígena, fábricas ocupadas, software livre, entre outros.

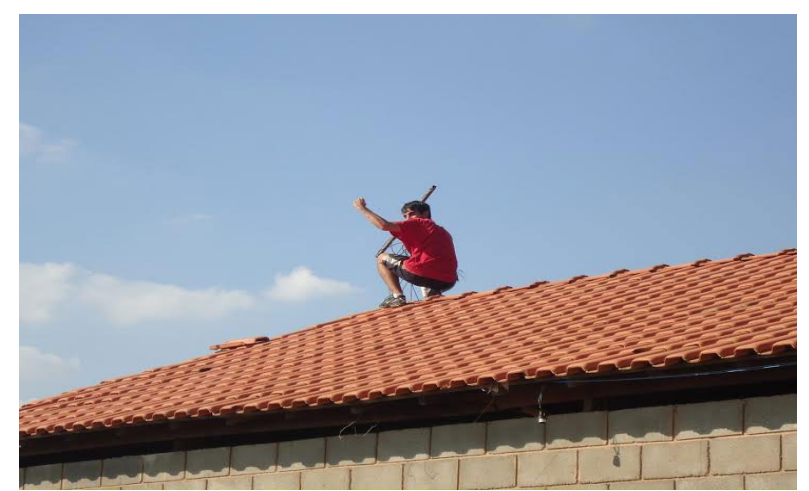

Figura 1: Instalação de antena de rádio em assentamento rural. Fonte: Fedel (2013).

Neste movimento dos trabalhos de campo, em um encontro de rádios livres (prática de pesquisa ação), realizou-se, coletivamente, uma atividade de recartografia com o objetivo de se criar uma ferramenta popular para entender e refletir as representações latentes no desenvolvimento dos coletivos (FALS BORDA, 1981) e compreender o espaço social produzido pelas rádios livres e seus integrantes.

Apoiamo-nos em Heidrich (2010), o qual propõe que, através da (re)construção de mapas, utilizando das artes visuais e do conhecimento geográfi- co, pode-se construir um espaço público de debate. A descartografia proposta provocou graficamente a tensão-espaço em territorialidades conhecidas, como também se lastrou através de memórias de ocorrências relacionadas às ações ostensivas da Polícia Federal e ANATEL em rádios livres, fomentando, também, várias pautas dos movimentos sociais. $\mathrm{Na}$ construção do mapa, motivou-se a representação das fronteiras entre o Brasil e países onde já se havia avançado em políticas de comunicação social, apresentando menos centralização e projetos onde se realiza a construção de transmissores FM para associações e entidades da organização civil (Argentina e Venezuela). Outras marcações foram realizadas, demonstrando a mobilidade dos integrantes e a origem das rádios grafadas pelos descartógrafos dos coletivos de rádios livres (ver Figura 2).

Por fim, em termos metodológicos, os movimentos de pesquisas, a descrição efetivada em termos dos arranjos espaciais produzidos pelos coletivos de rádios livres, foi uma tática de investigação conscientemente escolhida pelos pesquisadores como tentativa de produzir uma sintonia entre o movimento da comunicação livre e a nossa incursão científica.

\section{PRINCIPAIS QUESTÕES/PONTOS DESENVOL- VIDOS}

A desigualdade de distribuição das técnicas é evidente, assim como a produção de sentidos e a política de comunicação. O panorama em que a comunicação está inserida é extremamente próximo ao contexto das cidades e do planejamento urbano que é perpetuado. Assim, o surgimento das rádios livres está majoritariamente ligado às insurgências de grupos que eram reprimidos pelo Estado e que, de alguma forma, conseguiram utilizar a técnica de radiodifusão para promoção de um debate público relacionado às comunidades e a grupos sociais cujos anseios e direitos são, de algum modo, vilipendiados.

Na Rádio Muda, formada em 1994, em Campinas, localizada dentro da Universidade Estadual de Campinas (UNICAMP), estabelece-se, atualmente, uma grade com mais de cinquenta programas mensais, com uma variedade temática e política muito grande. A circulação de músicos, artistas, estudantes, 


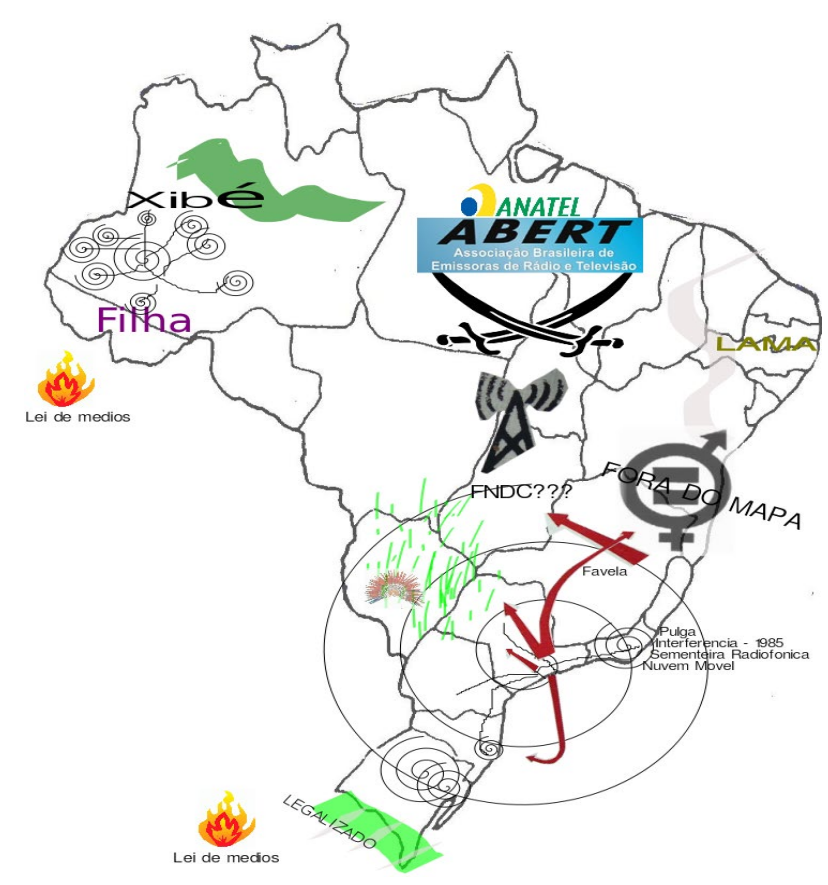

Figura 2: Recartografia da comunicação livre. Fonte: Fedel e Alvares (2013).

representantes de movimentos sociais, professores, trabalhadores e trabalhadoras da área urbana e rural faz com que o alcance das transmissões da Rádio Muda seja muito relevante. Também é expressivo o público que participa dos festivais realizados na praça localizada em frente ao estúdio, e esse grande 'público', que, ao mesmo tempo está ouvindo e, também comunicando, estimula o programador, como constatamos, à formação contínua de informação. $\mathrm{O}$ coletivo, não representativo, também busca articular ações de apoio mútuo com organizações populares, afim de difundir e construir uma comunicação popular. A independência técnica é viabilizada pela apropriação de softwares livres, e a organização interna é definida através de reuniões semanais.

Após a inserção em listas de discussões nacionais e latino-americanas, através da Internet, comunicamo-nos com os integrantes da Rádio Capivara, também localizada dentro de uma universidade pública, a Universidade Federal de São Carlos (UFSCAR), em São Paulo. A rádio existe há mais de 10 anos e sempre contou com parcerias de entidades estudantis para realização de atividades culturais e de formação técnica. Atualmente, a Capivara também conta com um estúdio utilizado por muitas bandas independentes as quais, através de uma di- nâmica colaborativa, utilizam, também, os instrumentos e aparelhos de som. A partir do uso do estúdio, firmam-se parcerias para shows quando a rádio necessita angariar recursos.

A Rádio da Juventude, diferentemente, localiza-se na periferia de São Vicente, litoral de São Paulo. Com uma grade de programas menor, dialoga muito com a comunidade em que está ambientada, constituindo-se em um centro de atividades culturais para os bairros próximos e ocupações urbanas. A rádio funciona há aproximadamente três anos, e os integrantes, com auxílio da organização de apoio, estreitaram a relação com a comunidade e possibilitaram que moradores dos bairros próximos realizem seus próprios programas.

Sobre as rádios pesquisadas, a conquista do espaço físico - o estúdio - deu-se através de um longo processo de legitimação das atividades, aliado às outras organizações políticas como Diretórios Estudantis (Rádio Muda e Capivara) ou entidades ligadas aos setores operários da Igreja Católica e Associação de Moradores (no caso a Rádio da Juventude). Os equipamentos são facilmente adquiridos em lojas convencionais de áudio e vídeo. Também é realizada a construção dos mesmos, como é o caso de alguns transmissores FM e respectivas antenas constatados em nosso campo.

Por serem grupos heterogêneos e articulados por relações não-capitalistas, mas inseridos em uma sociedade capitalista de classes, os integrantes das rádios livres que participaram da pesquisa procuram gerir suas atividades a partir de princípios como a autogestão, a horizontalidade e a independência política e financeira. Isso faz com que a multiplicidade de atividades seja grande e ao mesmo tempo produza uma baixa coetaneidade ou uma coetaneidade fragmentada (MASSEY, 2008) e os níveis de participação política sejam diversos. Nos trabalhos de campo, pudemos observar que há muitos integrantes com propósitos diferentes, desde aqueles que simplesmente realizam um programa pela simples vontade de 'tocar' músicas, até membros que estão inseridos em entidades e organizações populares com objetivos explícitos. Há integrantes que participam da rádio há poucos dias e há os que acompanham a rádio desde o momento de sua criação, como por exemplo, na Rádio Muda, com mais de 20 anos de existência. 
Essa diversidade de participação é, ao mesmo tempo, uma dificuldade e uma maneira de ampliação da territorialidade das rádios livres.

Com as rádios livres pesquisadas, vislumbrase a potencialidade para o planejamento urbano, o acesso à cidade e o direito à comunicação, culminando na enunciação de iniciativas que tratam de áreas invisíveis da cidade, seus indivíduos, suas práticas espaciais e suas construções sociais da realidade.

\section{QUESTÕES ABERTAS}

Juntamente com a facilidade de apropriação técnica da radiodifusão, os arranjos espaciais para a constituição das rádios potencializam a visibilidade de grupos historicamente marginalizados. Por outro lado, potencializa o diálogo entre "os pares": sujeitos provindos de múltiplas trajetórias, gerando novas sociabilidades. Embora os enfoques sejam díspares (feminismos, lutas pela habitação, visibilidade artística e estética, etc.), podem contribuir para fundamentar lugares de ações políticas em que se possam articular as identidades (diferença) dos indivíduos humanos enquanto "portadores de uma dignidade essencial" (SOUZA, 2001, p.157).

Com a pesquisa concluída, pode-se afirmar que as rádios livres produzem um espaço geográfico amplo e fecundo. Destaca-se a importância de distinção, em todos os momentos de entrevistas e acompanhamentos durante a pesquisa, da política na dimensão institucional para aqueles que frequentam estes espaços de experiência social que geram novas sociabilidades. Nota-se que a intenção de romper com uma prática política institucional é gradual e vem sendo realizada à medida que estes espaços autônomos se consolidam. Como movimentos de bases comunitárias não institucionalizados e simultaneamente alicerçado aos movimentos transversais (outros temas associados) e com uma distribuição diferenciada da técnica, as rádios livres proporcionam múltiplas trajetórias espaciais para que estes integrantes - os programadores - encontrem espaços com princípios autonomistas para diálogos e atividades intensas de suas afinidades políticas e sociais, compondo lugares de enunciação da cidade. Cidade(s) invisível(eis) que são por eles produzidas em suas falas e suas ações. Esses lugares favorecem uma produção social de outra escala geográfica, pois tratam de temas marginalizados e de áreas da cidade invisíveis, utilizando uma linguagem própria para expressarem suas liberdades.

Nota-se a necessidade de reflexão sobre a universidade, as rádios livres e a noção de espaço público, que enquanto as rádios podem ser consideradas um entre lugar de aconteceres políticos solidários, ele por estar inserido no recorte político- administrativo de uma instituição do Estado, é gestado por maneiras de organização que conflitam-se e contradizem-se sobre quais são as práticas sociais legitimadas neste espaço. Ao mesmo tempo em que se percebe que alguns coletivos de rádios livres restringem-se à participação majoritária da comunidade acadêmica e em que não há relações de tensão e conflito, observamos com um grau elevado incursões da polícia federal, ANATEL e a vigilância patrimonial das universidades ${ }^{3}$ atuando de maneira inconstitucional e controversa. Assim, por serem rádios não autorizadas, ou seja, não possuírem uma concessão do espectro eletromagnético perante o Estado Brasileiro (porém, legitimadas pelo público ativo), elas são ostensivamente repreendidas por órgãos como a Polícia Federal e a ANATEL. Salienta-se da produção política da escala geográfica $(\mathrm{SMITH}$, 2000), a urgência de um debate público das relações entre a soberania territorial do Estado (SMITH, 1996) e as iniciativas populares (comunidade política) advindas das rádios livres.

\section{REFERÊNCIAS BIBLIOGRÁFICAS}

ANDRIOTTI, Cristiane. D. O Movimento das Rádios Livres e Comunitárias e a Democratização dos Meios de Comunicação no Brasil. 2004, 232 fh. Dissertação (Mestrado em Sociologia). Instituto de Filosofia e Ciências Humanas, Universidade Estadual de Campinas (Unicamp), Campinas.

BAUER, Martin. W; AARTS, Bas. A construção do Corpus: Um Princípio Para a Coleta de Dados Qualitativos. In: BAUER, Martin. GASKELL, George. (orgs). Pesquisa Qualitativa com Texto, Imagem e Som: Um manual prático. 7 ed. Petrópolis: Vozes, 2008. p. 39-63.

BRIGGS, Asa; BURKE, Peter. Uma História Social da 
Mídia: de Gutenberg à Internet. 2 ed. Rio de Janeiro: Zahar, 2006.

CERTEAU, Michel de. A Invenção do Cotidiano: 1. artes de fazer. 3 ed. Petrópolis: Vozes, 1998.

COSTA, Mauro S. R. Rádio, arte e política. Rio de Janeiro: EdUERJ, 2013.

DOWNING, John. D. H. Mídia Radical: Rebeldia nas comunicações e movimentos sociais. São Paulo: Editora Senac, 2002.

FALS BORDA, Orlando. Aspectos teóricos da pesquisa participante: considerações sobre o significado e o papel da ciência na participação popular. In: BRANDÃO, Carlos Rodrigues. (org.) Pesquisa participante. São Paulo: Brasiliense, 1981. p. 42-62.

FLICK, Uwe. Entrevista Episódica. In: BAUER, Martin. GASKELL, George.(orgs). Pesquisa Qualitativa com Texto, Imagem e Som: Um manual prático. 7 ed. Petrópolis: Vozes, 2008. p.114-136.

GONÇALVES, Flora. R. Rádios Livres: As controvérsias ainda pairam no ar? Uma análise antropológica das novas relações sociais de radiodifusão. 2010, 160 fh. Dissertação (Mestrado em Antropologia Social). Universidade Federal de Minas Gerais, Belo Horizonte.

GONÇALVES, Flora. R. Apropriações libertárias sobre o espectro radiofônico: as Rádios Livres. Revista Espaço Científico Livre. Brasil, n.7, p.08-19, abr-mai de 2012.

GUARESCHI, Pedrinho Arcides; BIZ, Osvaldo. Mídia e Democracia. Porto Alegre: Editora Evangraf, 2005.

HEIDRICH, Álvaro Luiz. Esquema para dialogar com descartógrafos. In: WASHINGTON, Cláudia; ARAÚJO, Lúcio de; GOTO, Newton. (orgs.). Recartógrafos. Curitiba: edição do autor, 2010, v. 1, p.33-41. Disponível: <http://labes.weebly.com/uploads/4/2/5/4/42544/ esquema_para_dialogar_com_descartgrafos.pdf.>. Acessado em 01 de julho de 2013.

LIAKOPOULOS, Miltos. Análise Argumentativa. In: BAUER, Martin. GASKELL, George (orgs). Pesquisa Qualitativa com Texto, Imagem e Som: Um manual prático. 7 ed. Petrópolis: Vozes, 2008. p. 218-243.

MACHADO, Arlindo; MAGRI, Caio; MASAGÃO, Marcelo. Rádios Livres. A reforma agrária no ar. São Paulo: Ed. Brasiliense, 1987.

MASSEY, Doreen B. Pelo Espaço: Uma Nova Política da Espacialidade. Rio de Janeiro: Bertrand Brasil, 2008.

NUNES, Marisa. A. M. Rádios Livres: O Outro Lado da Voz do Brasil. 1995. Dissertação (Mestrado em Jornalismo). Escola de Comunicação e Artes, Universidade de São Paulo, São Paulo.

ORTIZ, Renato. Um Outro Território: Ensaios sobre a Mundialização. 2 ed (Ampliada). São Paulo: Editora Olho D'água, 2000.

PORTAL ESPECTRO LIVRE. Disponível em: <http://espectrolivre.org/>. Acessado em diversos momentos.

SANTOS, Milton. Técnica Espaço Tempo: Globalização e meio técnico-científico informacional. 5 ed. São Paulo: EDUSP, 2008.

SERPA, Angelo. Lugar e Mídia. São Paulo: Contexto, 2011.

SMITH, Graham. Teoria política e geografia humana. In: GREGORY, Derek; MARTIN, Ron; SMITH, Graham (orgs.). Geografia Humana: Sociedade, Espaço e ciência social. Rio de Janeiro: Zahar, 1996. p. 65-89.

SMITH, Neil. Contornos de uma política espacializada: Veículos dos sem teto e produção de escala geográfica. In: ARANTES, Antonio (org.). O Espaço da diferença. Campinas: Papirus, 2000. p. 132-175.

SOUZA, Marcelo José Lopes de. Território do outro, problemática do mesmo? O princípio da autonomia e a superação da dicotomia universalismo ético versus relativismo cultural. In: CORRÊA, Roberto Lobato; ROSENDAHL, Zeny (orgs.). Religião, identidade e território. Rio de Janeiro: EdUERJ, 2001, p. 145-176.

THIOLLENT, Michell. Metodologia da pesquisa-ação. 5 ed. São Paulo: Cortez/Autores Associados, 1992. 


\section{Notas de Fim:}

1- Portal Espectro Livre: <http://espectrolivre.org/>.

2- Entende-se aqui "Coletivo" como uma organização não hierárquica, não representativa, composta por pessoas que decidem suas ações através do diálogo consensual e, também, do dissenso, pois assim é que a diversidade de opiniões encontra oportuno debate e, consequentemente, ações diferenciadas. Reconhecer o "outro" é passo fundamental na composição dos coletivos.

3-<https://www.youtube.com/watch?v=u7NiHGM5oLQ> (ação de fechamento pela PF na Rádio Filha da Muda - Acre). < https:// www.youtube.com/watch? $v=O g J a 4 M 4 p W a c$ (tentativa de fechamento da Rádio Muda pela ANATEL). <https://www.youtube. com/watch?v=B24OHpBdUGY> (ação da vigilância patrimonial da UNICAMP na Rádio Muda), mais notícias e informações sobre $:<$ http://radiolivre.org $>$.

\section{Correspondência dos autores:}

André de Souza Fedel

e-mail:drefedel@gmail.com

Almir Nabozny

e-mail: almirnabozny@yahoo.com.br

Artigo recebido em: 09/11/2015

Aceito para publicação em: 28/03/2016 